\title{
The Porosity of Autonomy: \\ Social and Biological Constitution of the Patient in Biomedicine
}

\author{
By Jonathan Beever and Nicolae Morar ${ }^{1}$
}

\begin{abstract}
The nature and role of the patient in biomedicine are issues central to bioethical inquiry. Given its developmental history grounded firmly in a backlash against $20^{\text {th }}$ century cases of egregious human subjects abuse, contemporary medical bioethics has come to rely on a fundamental assumption: the unit of care (and the unit of value) is the autonomous self-directing patient. In this paper we examine first the structure of the feminist social critique of autonomy. Then, we show that a parallel argument can be made against relational autonomy as well, demonstrating how this second concept of autonomy fails to take sufficiently into account an array of biological determinants, particularly those from microbial biology. Finally, in light of this biological critique, we question whether or to what extent any relevant and meaningful view of autonomy can be recovered in the contemporary landscape of bioethics.
\end{abstract}

\section{Introduction}

The nature and role of the patient in biomedicine are issues central to bioethical inquiry. Given its developmental history grounded firmly in a backlash against $20^{\text {th }}$ century cases of egregious human subjects abuse, contemporary medical bioethics has come to rely on a fundamental assumption: the unit of care (and the unit of value) is the autonomous self-directing patient. Respect for autonomy, one of the key normative principles at work in bioethics, provides a historically important liberatory and moral standard by which to evaluate judgments and behaviors and to adjudicate between possible avenues of action. Its status as moral standard in the context of U.S bioethics derives from its origins in the 1974 National Commission for the Protection of Human Subjects of Biomedical and Behavioral Research; the Commission's Belmont Report, published in 1979, continues to ground much of the current research ethics policy in the U.S. (e.g. Beauchamp and Childress 2013). In this context, respect for autonomy is a direct societal and professional response to transgressions of research integrity as evidenced in the Tuskegee Study of Untreated Syphilis in the Negro Male (CDC 2014). Autonomy itself, as a capacity of individual persons, is further enriched by the liberal self-rule ethos prevalent in Western culture: in that setting, it acts as a liberatory standard toward control and self-rule within the medical setting. Here, a certain conception of the self is seen as doing most of the conceptual work: the self does not simply point to the ontological status of the individual (e.g. a particular psychological integrated unity); but, in contrast, it highlights the individual, as a free and rational agent, as the source of normative claims

\footnotetext{
${ }^{1}$ Affiliations: Jonathan Beever, Department of Philosophy, University of Central Florida; Nicolae Morar, Department of Philosophy and the Environmental Studies Program, University of Oregon (nmorar@uoregon.edu-corresponding author).
} 
whose thrust is to support the liberatory aspects of autonomy. These two functions of autonomy, as liberatory and moral standard, are necessarily built upon an account of the individual and of agency in a particular sociopolitical and historical context.

However, this conception of the biomedical patient as autonomous self-directing agent has been criticized widely - particularly by feminist theorists - for failing to take into account situated and relational social determinants of the individual that cause and/or constitute and/or compromise autonomy in decision-making. In a related line of critique, bioethicists have also argued that autonomy is either specified differently or is not as salient a norm in many international settings as it is in the Western context (e.g., Marshall et al 1994; Akabayashi and Hayashi 2014), further threatening the historical assumptions about agency, autonomy, and the individual. These lines of argumentation point out at least to two theoretical possibilities in bioethics: reconceive autonomy or jettison it.

Rather than throw the baby of autonomy out with the bathwater of the individual, a number of critics have worked to amend the concept of autonomy for applicability under particular relational conditions (e.g., family, community, society). We think the support for retaining autonomy has to be grounded beyond our psychological constitution; specifically, in biologically-informed ontology.

In this paper, we examine the structure of the feminist critique and then show that a parallel argument can be made against this revised (relational) concept of autonomy as well, demonstrating how this second concept of autonomy fails to sufficiently take into account an array of biological determinants. Certainly, so far, biological evidence is still developing. Yet, the microbial picture emerging from microbial biology shows that certain categories that are necessary conditions for autonomy - like individualism - might not have sufficient justification in a naturalistic context. Thus, while we align with those claims that wish to extend the concept of autonomy to include constitutive relationality, we also want to point out that any notion of autonomy could be questioned if the ontology it requires is ultimately flawed. We argue that even a relational account of autonomy does not go far enough toward recovering autonomy and its corresponding account of individual agency for contemporary bioethics. However, if the background assumptions (atomism, individualism, complete self-determination \& self-deliberation) for autonomy are false (or at least highly questionable), then, can we still retain a meaningful and morally efficacious conception of autonomy? We argue, along with the feminist discourses around autonomy, that there are strong normative reasons to desire to retain the sorts of core values that autonomy upholds in bioethics. While the feminist tradition has called into question a certain conception of autonomy, it has not completely abandoned this concept even when feminists were pressed to explain particularly challenging cases (forms of excessive deference, adaptive preferences modulated by oppressive social conditions, and perpetuating forms of gender oppression). Yet, despite strong normative reasons to retain the values autonomy supports, we argue they cannot be supported by a concept that might be fundamentally flawed. Thus, finally, we question whether or to what extent any relevant and meaningful view of autonomy can be recovered in the contemporary landscape of bioethics and how, if not, the normative weight of autonomy can be otherwise upheld.

Autonomy 1.0

Autonomy, in its historical conception in medical bioethics, assumes a strong view of individuality and agency. This account of individuality is an account that set up the individual as wholly and even 
necessarily self-sufficient, self-determined, self-guided - in a word atomistic, - who is entirely free to make his or her own choices independent from social inputs. This seems to be the ideal established by the authors of the Belmont Report: "An autonomous person is an individual capable of deliberation about personal goals and of acting under the direction of such deliberation" (National Commission 1978: 5). Further, some individual contributors to the Report agree with making the strong link between autonomy and self-determination. Robert Veatch, for instance, uses the terms interchangeably (Veatch 1976: 26-5, 26-19, 26-25).

However, such a strong view would establish, at least to some extent, a straw man too easily knocked down: no such idealistically atomistic individual exists in practice. Indeed, from its earliest bioethical development in the Belmont Report, autonomy has been seen as both centrally important and conceptually complex. The Report itself, while upholding the ideal of selfdetermination, acknowledges too that circumstances may incapacitate the otherwise autonomous individual. Thus, the Report notes, that "not every individual is capable of self-determination" for a variety of reasons including "illness, mental disability, or circumstances that severely restrict liberty" (National Commission 1978: 5). Robert Levine, in his 1975 contribution to the National Commission (published as an appendix to the Belmont Report), acknowledges the complexity in their discussion of forms of constraint on decision-making: "It is possible to question whether any individual who perceives himself as a member of society is totally free to make choices regarding the disposition of his own body" (Levine 1975: 3-34). More strongly yet, Levine later notes: "It is concluded that any person who assumes the 'sick role' is incapable of complete autonomy" (National Commission 1978b: 3-83). In the context of particular cases, the strong view of autonomy is weakened by external circumstances like illness or forceful constraint.

Similarly, another of the central proponents of the normativity of autonomy in bioethics, James Childress, took issue with this link even while recognizing its centrality: "the principle of respect for autonomy is ambiguous because it focuses on only one aspect of personhood, namely selfdetermination... we would have to stress that persons are embodied, social, historical, etc." (Childress 1990: 13). Childress here is responding to this now common criticism of the place of autonomy in bioethics; specifically, its connection to a particularly limited view of the individual as merely or fundamentally self-determined. ${ }^{2}$ But Childress's account of autonomy remains indebted to the idealist account of the individual. For Childress, while we, in practice, have reason to give up the ideal of autonomy - what he calls "first-order autonomy" (Childress 1990: 13), - he holds on to the idea of "second-order autonomy" (ibid). On his view, autonomy might be overridden but remains a core and fundamental condition of the individual patient. "It is important for the moral life that people be competent, be informed, and act voluntarily. But they may choose, for example to yield their first order decisions... Abdication of first order autonomy appears to involve heteronomy, that is, rule by others...” (Childress 1990: 13). This view treads an uncomfortable line since it forces individual responsibility onto heteronomy, as a willing giving-up of first order autonomy. The same view is reflected in Childress's work with Tom Beauchamp in their seminal Principles of Biomedical Ethics text. There, the authors recognize non-ideal conditions for the autonomous individual's action and analyze autonomous individuals as "normal choosers who act

\footnotetext{
${ }^{2}$ There are, of course, several other types of criticisms at work. For instance, Joffe et al demonstrated experimentally that patients tended to value a shared decision-making environment over one, which normatively privileged a narrow account of autonomy as brute self-determination, further weakening the strong view of the concept. (Joffe et al 2003: 106-107)
} 
(1) intentionally, (2) with understanding, and (3) without controlling influences that determine their action" (Beauchamp and Childress 2013: 104).

But these conditions, addressed from the Belmont Report through the ongoing work of Beauchamp and Childress, are based on the assumption of the metaphysical priority of an autonomous chooser. This autonomous agent rides in the metaphysical driver's seat and is affected, secondarily to his or her free choice, by external nonideal conditions. Thus, the authors conclude, “... no fundamental inconsistency exists between autonomy and authority if individuals exercise their autonomy in choosing to accept an institution, tradition, or community that they view as a legitimate source of direction" (Beauchamp and Childress 2013: 105). For Childress and Beauchamp, the effects on autonomy - those effects that make autonomy, in practice, nonideal - are accounted for in terms of an ethical analysis of concerns about justice (Beauchamp and Childress 2013: 106). The controlling influences one chooses, or those influences that unintentionally lead to compulsion or coercion, are simply failures of autonomous choice that can be accounted for by a secondary account of equitable distribution of harms and benefits. Even if no such idealistically atomistic individual exists in practice, the concept of such an individual continues to play an important role at the theoretical and normative levels. Hence, on the view of Autonomy 1.0, autonomy still deserves respect as the central foundation of individual action and moral worth. The individual, on this view, is metaphysically prior to secondary causal constraints on his or her autonomy.

While there are clearly good reasons for holding on to the idealist view of the autonomous individual, - most notably the protection of human subjects in medical research and treatment, the underlying metaphysical assumptions about what constitutes the individual patient, the unit of care in biomedicine, give short shrift to other environmental, relational, and social considerations. Indeed, it is this same critique that has grounded many feminist critiques of the fundamental assumptions of medical bioethics. These critiques, that the idealist account is both practically unreliable but also metaphysically overstated, have led to a reconsideration and reframing of autonomy as a morally-relevant attribute of the individual agent. If the idealist conception of individuality as the ground of autonomy is so problematic, then bioethicists are compelled to reconsider whether the notion of autonomy can be rescued and grounded on a more reliable set of premises. This is precisely the work within bioethics of those feminist and social psychological critics mentioned above, all of whom wish to salvage autonomy by reframing it in terms of an (at least in part) socially constituted individual.

\section{Autonomy 2.0}

The view of the role of social determinants in autonomous action mentioned above is developed in the context of the patient/physician relationship, offering an explanation of why, when the patient subjects to the physician's decisions, we can still understand that patient as autonomous. Yet subjecting to a physician's decision is a particular instance of the individual giving up her free choice - her first order autonomy - due to or caused by social determinants; in this case, her understanding of the epistemic role of professional knowledge. On this account, the (second-order) autonomy of the patient is preserved precisely because the patient is accepting social determinants - in this case the heteronomous ruling of the physician - as part of her autonomous constitution as an individual. But other instances of the giving up of free choice due to social determinants make such an account less comfortable. Consider the case of domestic violence: an account of autonomy that accepts the causal role of social determinants might suggest that instances of domestic violence 
could be, analogously, the result of the active giving-up of first order autonomy by the victim (when s/he does not seek out help or a safe environment) in order to be heteronomously ruled by the violent partner. ${ }^{3}$ How can we make sense of all those cases when the victims integrate, and ultimately accept, forms of repressive behavior in their daily lives? Such implications find ethical fault with the metaphysical (and moral) priority of individual autonomy: autonomy cannot so easily incorporate the causal role of social factors.

Thus, critics claim that the biomedical view of autonomy, the view that focuses on coercion, internal compulsion, and ignorance as barriers to a more fundamental autonomous individuality, is inaccurate or incomplete. Social psychological, feminist, and causal critiques have been leveled against this view (e.g., Donchin 2000, Baier 1981, Nedelsky 1989, Mackenzie and Stoljar 2000, Barclay 2000, Christman 2004 and 2009 and 2014). In line with such critiques, a more compelling reading of examples like the domestic violence and patient submission examples would be to conclude that the autonomous individual is more clearly understood as constructed in rather than merely causally constrained by a network of social and psychological variables.

In response to problems of the individual autonomy in medical bioethics, many have posited variations on a restructured conception of individuality in support of, in turn, a revised autonomy some version of an Autonomy 2.0. Some variations have focused on merely causal critiques, bringing social justice concerns to bear more centrally on traditional or mainstream medical bioethics' view of autonomy and individual agency (see Donchin 2000; Christman 2004, 2009, 2014; Sherwin 2000). Others have worried the metaphysical views underlying these concepts, bringing to bear a stronger constitutive rather than merely causal critique (see Baier 1981; Nedelsky 1989; Barclay 2000). A merely causal view avoids commitments to an ontological view of the individual, arguing instead that, whatever the individual is, she faces external constraints that cause alterations to her free choice and scope of possible actions. A constitutive view, alternatively, does take an ontological stance, arguing that the individual is fundamentally made up of or constituted by her relations. The relationship between causal and constitutive critiques for a particular view of autonomy is important: the further toward the constitutive side the argument is pushed, the less traction individual autonomy can get on the terrain of bioethics.

The focus on causal critiques calls attention to the effects that social and interpersonal relationships have on autonomy via their impacts on individuality. Anne Donchin, for example, argues for a strong relational autonomy that accounts for both subjective (interpersonal) and objective (environmental/cultural) factors. On her view, autonomy is fundamentally "both reciprocal and collaborative" (Donchin 2000: 239). "It is reciprocal in that it is not solely an individual enterprise..." (240). Instead, the autonomous self "affected, and perhaps partially constituted, by the changing circumstances to which it is exposed" (Donchin 2000: 240). On the collaborative side, Donchin claims that a social relational account of the self "... will take into account the network of relationships that bears on individual efforts to be self-determining, responsible agents" (Donchin 2000: 240). This network of relationships affects the individual by placing constraints on the possibilities of autonomous choice and action. These relationships affect autonomy causally, changing the range of options for choice and action from the outside. Donchin's goal is the

\footnotetext{
${ }^{3}$ Cf. McLeod and Sherwin (2000:250) on the role of oppression in interfering with a person's ability to act autonomously and Nedlesky (2011: 53 and 176) on a nuanced conception of autonomy in similar cases.
} 
reinterpretation of individual autonomy that steers "a path between two risks: that individual selfdetermination will be overwhelmed by more encompassing social aims and that self-determination will be afforded so much importance that power imbalances are allowed to persist under the guise of autonomous self-determination" (Donchin 2000: 240). This middle path seeks to maintain autonomy while complicating the idealist conception of the unencumbered autonomous individual.

In terms of the patient in biomedicine, Donchin includes a brief recognition of "genetic and biological ties" but only insofar as genetic or other biological information exacerbates social injustices within existing social institutions like families (Donchin 2000: 241). Strong emphasis on interpersonal causal constraints on autonomy may be the impetus for Beauchamp and Childress's lukewarm response to such feminist critiques. Namely, by accepting the feminist social justice critique while remaining committed to their defense of autonomy in bioethics they suggest, subtlety, that feminists like Donchin have missed the conceptual boat: they conflate social justice issues with metaphysical claims about individuals and ethical claims about autonomy, claiming that the former's causal role on the latter is somehow a critique of the concept of the autonomous individual.

John Christman, too, is committed to maintaining autonomy via a centrally causal critique of the idealist view of the autonomous individual. In his work on paternalism, Christman recognizes that there is much to be wary about in autonomy-based approaches to paternalism but is interested in approaches that "avoid their most prominent pitfalls and hopefully retain their evident virtues" (Christman 2014: 380). While autonomy remains of central concern and interest for Christman, he is more critical of the individualistic foundation from which it has historically been leveraged. Christman argues that bioethicists understanding of paternalism would significantly change "if we abandon the overly individualistic understanding of self-government we inherit from these standard approaches" to autonomy (Christman 2014: 381). Indeed, the alternative Christman has worked to unpack is that of socially and socio-historically constituted selves (Christman 2004 and 2009) that "are autonomous only when that variable and multiplex position in those social relations reflects the authentic and self-imposed standards of the free person" (Christman 2004: 158). Autonomy is significantly impacted by the individual's positioning in the network of social relations, which cause change to the range of autonomous decisions available in any particular context. But to make the further metaphysical claim that the individual is constituted by those relations is "a more dangerous and ultimately problematic move" (Christman 2004: 158) in that it leads back to a perfectionist view of individuals that "denies the reality of change over time, variability in self-conception, and multiplicities of identity...” (Christman 2004: 145). Christman, like Childress, wants to maintain the ethical ideal of autonomy while giving up the practical ideal. The goal of Christman's approach is to avoid the "overarching paternalism that attention to autonomy should well protect against" (Christman 2004: 158). So, while practically speaking bioethicists should avoid perfectionist views of the autonomous individual (whether isolationist or constitutive), the ethical ideal of autonomy remains an important safeguard against overwhelming paternalism. For Christman and Donchin both, focus on autonomy must recognize the ways that social factors affect it by affecting the individual on which it stands.

A range of related critiques have pushed the role of social relations beyond their causal roles to argue that these networks of relations are fundamentally constitutive, in a deeper metaphysical sense. Unlike several of her feminist colleagues who understand social relations causally, Annette Baier focuses on the metaphysical questions that underlie considerations of autonomy and individual agency. On her view, the very development of personhood or individuality requires relations of 
interpersonal dependency. As Baier comments, "We acquire a sense of ourselves as occupying a place in an historical and social order of persons, each of whom has a personal history interwoven with the history of a community" (Baier 1981: 187). While some have claimed that Baier's position supports a causal view of the development of persons (MacKenzie and Stoljar 2000: 7), it stands to support a bolder view of persons as not only affected but instead or also constituted by social relations. Baier's "second-persons" are either wholly or at least in large part contingent on "other persons who formed and cared for them..." (Baier 1981: 181). Jennifer Nedelsky, like Baier, criticizes idealist individual autonomy for failing to recognize the constitutive role of social and interpersonal relations. She recognizes the normative merit of autonomy to the projects of feminism (Nedelsky 1989: 7) as "not only a term, but a basic value" (Nedelsky 1989: 11). She maintains this view in her 2011 book, arguing there at "the relational self can claim dignity as well as autonomy" (30) and concluding, "a culture that values autonomy and understands autonomy in relational terms will be better equipped to treat everyone with respect" (65). However Nedelsky wants to shift the foundation on which autonomy is based. She claims that "we come into being in a social context that is literally constitutive of us" (Nedelsky 1989: 8), although not determining of us (Nedelsky 2011: 32). This social context, and the collective of interrelations that makes it up "...is not simply a potential threat to individuals, but is constitutive of them, and thus is a source of their autonomy as well as a danger to it" (Nedelsky 1989: 21). The social constitution of the individual, on views like these, is the source of autonomy as it is the source of the individual. But Nedelsky recognizes the fine line between the social constitution of autonomy and the overwhelming constraints that might lead towards heteronomy. Others, like Linda Barclay, have argued the more definitive line in defense of a reconceived autonomy that, in principle, "these strong versions of the social self are not in fact plausible and thus should not threaten our commitment to a suitable conception of autonomy" (Barclay 2000: 53). Even on the strong constitutive view of Autonomy 2.0, proponents like these seek to maintain the normative force of autonomy.

Critiques like the ones outlined above evidence just that social relations do, at least to some extent and causally if not constitutively, play an important role in autonomy by their impact on the practical place and nature of the individual. Rethinking idealist individual autonomy in light of the role of social relations maintains the ethical importance and relevance of autonomy but charges that the medical bioethics view of autonomy based on atomistic individuality has misrepresented the concept descriptively, and that this misrepresentation has significant practical implications for understanding the patient in biomedicine.

As we have shown, a new conception of individuality emerges from the literature on relational autonomy. Autonomy has entailed (and overemphasized) an atomistic and abstract notion of an individual agent whose decisions, in order to be fully moral, had to spark from one's unobstructed capacity for self-determination. Supporters of relational autonomy accounts show that those premises are deeply flawed if not completely false. Unlike proponents of Autonomy 1.0 who assume that individual autonomous agents should be understood as separated from significant causal influences, Autonomy 2.0 highlights the important social aspects of individuality and the ways in which social vectors determine, motivate, and cause or in part constitute an individual's sense of autonomy and sense of agency. Yet Autonomy 2.0, like Autonomy 1.0, remains committed to the normative force of autonomy, a force directed to preserving respect for persons as a fundamental value. 
Given Autonomy 2.0, the challenge is to see whether the concept of autonomy becomes illusory, and as a consequence, a less compelling resource for bioethics. If "for every value, plan, or project endorsed by the self, there is a set of social influences that can account for why one makes the 'choices' one does" (Barclay 2000, 54), the notion of autonomy would simply dissolve given the pervasiveness of processes of socialization (i.e. some maximum degree of social determinism). In the last section of our essay, we will argue that this same challenge can be raised against Autonomy 2.0. Advocates of relational autonomy successfully point out that social relationships - family, culture, social status, etc. - have a significant impact on how each moral agent determines their values, goals, and more broadly, their conception of a good life. We fully endorse this claim, but we believe that in the context of health care and disease treatments, it is still incomplete in relevant ways - specifically, biological ones.

Of course, there are existing perspectives within a framework of Autonomy 2.0 that do seek to acknowledge biological impacts on individuality. Clyde Hertzman's work on biological embedding, for example, could stand as counter evidence to the idea that bioethical perspectives within the framework of Autonomy 2.0 do not acknowledge other ecological interactions, including biological ones. Hertzman argues that socioeconomic gradients have a direct causal role in health and health outcomes across the life of an individual (Hertzman 2006). Hertzmann's emphasis is on the ways in which social interactions, especially negative ones, cause biological change that becomes embedded in the systems functioning of the individual. Such an interaction, called biological embedding, represents "the process whereby differential human experiences systematically affect the healthfulness of life across the life cycle" (Hertzman 2006: 89). In other terms, the process occurs "when experiences get under the skin and alters human biological processes" in relevant ways (Hertzman and Boyce 2010: 330). However, this account aligns with Autonomy 2.0 views in that it relies on a causal account that integrates biological impacts and social factors on autonomy only as secondary to a robust account of self-determination and individuality.

In the feminist tradition, too, a few authors utilize biological themes in describing social embeddedness. Jennifer Nedelsky, in her 2011 Law's Relations, argues in a lengthy coda a view that accounts for "the basic equality of all human beings" and, at the same time, fosters "a respect and concern for the vast diversity of other life-forms (indeed all other forms of matter and energy)" (195). She does not think that "there can be optimal human-human relationships... in the context of violent disregard for our relations with the nonhuman world" (197). Yet even while Nedelsky pushes readers to think ecologically, the ecology is still built of external relations and holds tight to the view of the individual given by Autonomy 2.0. Lorraine Code's pioneering work in feminist epistemology is another example of the use of biological concepts in describing the nature of the autonomous individual. In Ecological Thinking (2006), Code employs ecological thinking both literally and metaphorically (51) to "unsettle assumptions about isolated, abstract, formal knowledge claims advanced and evaluated in isolation from their circumstances of their making and the concrete conditions of their possibility and from their consequent situational effects" (ix). Both of these theorists remain focused on social relations, emphasizing biological/ecological concepts either as a coda (Nedlesky 2011) or as a metaphor (Code 2006: 51).

Further, others have begun to examine an even more robust constitutive story about individuals, either from a developmental system or from microbial biology perspectives. Within environmental philosophy for example, Sean Lema builds on the developmental systems tradition (Lewontin, 2000; Oyama 2000; Oyama, Griffiths, \& Gray, 2001) in order to argue argues that each individual 
organism is constituted by a series of interactions with its environment, "interactions take primacy since it is interactions that shape an organism's development” (Lema 2014: 157). His account is informed by ecological and epigenetic literatures ${ }^{4}$ and builds a case for a richly interactive environment-organism reciprocity. This "causal reciprocity" (151) approach defends the view that "conceptual distinctions between 'organism' and 'environment' become obscure, so that when 'environments' change, so necessarily do 'organisms' conjoined to those environments, and vice versa" (160). Accounts like these evidence initial targeting of some of the core ontological commitments of Autonomy 1.0, but not from a bioethical or biomedical perspective. Along with this interactionist account that is emerging within environmental philosophy, we believe that recent findings in microbial biology help us provide an even more robust amendment to the Autonomy 2.0 view, especially when it plays a key role in biomedicine and bioethics.

\section{Autonomy 3.0: Paradigm Shift or Moral Fiction?}

While relational autonomy brings to our attention the importance of forces of oppression, like coercion, internal compulsion, and ignorance, whose dramatic effects on self-trust can significantly undermine autonomy, it assumes only a social-psychological conception of individual agency (Stoljar 2013, Section 8). To the extent that Autonomy 2.0 (relational autonomy) is employed in social and political settings, its incompleteness might not be revealed immediately. However, when it is imported into a medical setting, Autonomy 2.0 is seen to overlook the importance of organic/ biological/ ecological aspects of being a patient under treatment. Certainly, its proponents make a significant critical advance in recognizing the importance of social interactions in autonomy-related actions and/or judgments, but their exhaustive focus on social interactions is achieved at the expense of other ecological interactions, especially, as we will show, microbial ones.

Microbial biology is producing a radically new understanding of 'individual' organisms (O'Malley \& Dupré 2007; Dupré 2008 \& 2012; Bapteste \& Dupré 2013; O’Malley 2014) and an emerging series of ethical concerns (Rhodes, Gligorov, and Schwab 2013). Until recently we have thought of ourselves and of other organisms as being the kind of entities which possess fairly strict spatial boundaries and whose internal functioning was regulated by one's respective cellular materials (for a review of the problem of individuality in biology, see Wilson 2005; Clarke 2011; \& Wilson \& Baker 2013). To our own surprise, we have learned that "bacteria occupy all surfaces of the human body with a combined microbial cell population $\sim 10$ times that of human cells ${ }^{5}$ (Bäckhed \& al 2005; Kurokawa \& al 2007), “a fact which, in essence, makes us more microbe than man!” (Sleator 2010). We have also learned that everyone's microbiome makes possible physiological capacities that are not the product of our own evolution (Ley et al 2006; Turnbaugh et al 2006).

\footnotetext{
${ }^{4}$ This case offers further and more substantial biological evidence to developing views like that of J.S. Robert (2006). Robert has argued that epigenesis, the interaction between internal genomic processes and external environments, is constitutive not only of genes (xv and 74) but also of environments themselves. Robert concludes, "It is evident not only that organisms construct themselves within environments but also that they help to construct their environments" (87).

${ }^{5}$ The 10:1 ratio of cells is a factoid still promoted on the Human Microbiome Project website. In reality, we are close to a 2.5:1 ratio since human organisms consists of about 40 trillions human cells and the microbial cells constituting our microbiome is around 100 trillions cells (Ravel et. al. 2014). Thanks to Brendan Bohannan for this point of clarification.
} 
For example, recent studies have shown that specific gut bacteria provide some specific digestion power to cultural Japanese, and only to those Japanese. The study has identified in marine bacteria an enzyme that is particularly specialized in degrading algal cell walls. Interestingly, "the gene that codes for the enzyme has been found in one other place: the genome of Bacteroides plebeius, a microbe found in human intestines. However, not all B. plebeius strains produce the algae-crunching enzyme. It has only been found in Japanese people" (Keim 2010). The real upshot of this study is to show that only (some) Japanese people have the possibility to digest some algaes, and this process of digestion, which provides them with more nutrients from an algae-rich diet, is not the outcome of their organic structure but a service offered by the symbionts that inhabit their guts (Hehemann \& al. 2010).

In many ways, biological organisms are both an expression of a certain genetic composition and a manifestation of a metabolic system largely sustained by the fellowship of our microbial communities. This view has led some scientists to declare that we should not think anymore of ourselves (and of other organisms) as individuals (Gilbert, Sapp, \& Tauber 2013) but as communities or ecosystems (Xu \& Gordon 2003; Gordon \& al 2005; Bäckhed \& al 2005; Gordon \& Klaenhammer, 2011; Williams 2013). While individuation remains a conceptual tool for making sense of the world since it helps us describes the ways in which we identify an entity or ecosystem as being different from other things, the ecosystem view concerning our biological constitution denies the deeper ontological view about ourselves, as being individual (single \& indivisible).

If research has evidenced that microbial symbionts play a physiological role in the constitution of their host ecosystems, that research is also suggestive of the neuro-psychological role they play (some believe we face a paradigm shift in neuroscience, e.g. Mayer et al 2014). Additional literature emerging from microbial biology has shown that single-celled organisms, like Toxoplasma, can successfully alter the behavior of their hosts (i.e. rats) in order to be able to reproduce, up to the point where the host puts its survival at risk (Hari Daas \& Vyas 2014). Moreover, a central developing hypothesis, which certainly demands more evidence in order to be robustly established, is that in addition to the communication mechanisms that have been identified between gut microbiota and nervous system, the composition of this community has direct influence on mammal behavior (Foster \& Neufeld 2013). Evidence points towards "an effect of commensal gut microbiota on the central nervous system" (Bravo et. al. 2011), and it led biologists to label this mechanism as the microbiome-gut-brain axis (Cryan \& O’Mahony 2011; Cryan \& Dinan 2012; Foster \& Neufeld 2013). Microbial ecology plays a central role not only in understanding the individual as a community, but also in recognizing the ways that agency and autonomy are additionally impacted by microbial interactions. These studies point toward the way that microbial interactions constitute us as an ecosystem through gut-brain interactionism, and thus play a role in constituting individual affect and mental states through this gut-brain axis.

This newly emerging view of human individuals as living communities in constant interaction with their environment, especially in symbiosis with their environment, has direct impact on the way we assess patients in terms of their individual health, disease, and treatment. In a recent edited volume New Visions of Nature - Complexity and Authenticity (2009), Eric Juengst fleshes out some of those crucial implications. The war metaphor, which assumes that a disease is separable from its patients and they should fight against it like they should fight against any predator, is obsolete. "A new paradigm is needed that incorporates a more realistic and detailed picture of the dynamic interactions among and between host organisms and their diverse populations of microbes, only a 
fraction of which act as pathogens" (Forum on Microbial Threats, 2006; cited in Juengst 2010: 139). This new paradigm, unlike the previous one, which considered our relationship with microbes only in terms of negative causal interactions, assumes that our state of health is more likely attained when we are in a balanced and harmonious relationship with our microbial communities. If the ecosystem metaphor is the most appropriate way to describe our organic constitution (Dupré \& O'Malley 2010; Bohannan 2013; Nature 2008), then "human health is a matter of having one's physiological processes and predispositions aligned correctly to promote homeostasis, so that that body runs as much like a self-regulated and self-sustaining system as possible" (Juengst 2010, 140).

We believe that the conception of relational autonomy from Autonomy 2.0 is incomplete to the extent that it overlooks this deep biological interconnectedness between human individuals and other organisms. ${ }^{6}$ In order to highlight this point we will use the case of obesity as a recent example where social vectors have been proven very useful but still limited in their explanation of this phenomenon. The understanding and treatment of obesity has been primarily driven by a narrow epistemic focus. If initially most explanations were cast in terms of inherited/genetic features, weakness-of-character, or personal choice and responsibility (Nielsen and Andersen 2014), feminist and social critiques have highlighted the important role that social contexts - including economic conditions, poor diet, cultural acceptance or indifference, family relations, and peer influences play in the development of obesity (Callahan 2013). Relational autonomy accounts have challenged the idea of an autonomous individual by showing that we are fundamentally influenced, and probably deeply constituted, by social and interpersonal relations. Certainly, a number of public health efforts have been engaged in order to alter the social vectors involved in sustaining this phenomenon (food labeling and advertising, food assistance programs, urban development that encourages alternative modes of transportation, taxation, etc.). However, as Callahan notes (2013, 35), physicians continue to avoid discussing their patients' obesity with them since their lifestyles and a whole array of ecological conditions involved with obesity supposedly fall outside of the realm of medicine. And, even if physicians (and relational autonomy supporters) had considered the importance of ecological inputs with respect to obesity, they would still function under the implicit assumption that the unit of care is the organism, understood as a coherent set of interdependent and largely mechanical parts that can be explained and treated in isolation. Thus, such an account remains incomplete to the extent that neither genetic nor social conditions are wholly determinate of obesity. The fundamental role of microbial communities in our digestive systems has been largely ignored, if not completely overlooked (Ley et al 2006). ${ }^{7}$

Microbial biologists have provided evidence that the gut microbiota plays a significant role in the development of obesity. They have initially analyzed the differences in obese and lean human twins with respect to their gut microbial communities, and they have noticed that obese twins lack in

\footnotetext{
${ }^{6}$ Lorraine Code's book (2006) is certainly the closest in nature with the view we espouse in this paper. However, we still believe that there are some significant differences between Code's usage of the concept of ecology and our ecological conception of the human organism. As we note above ( $\mathrm{ftn} \# 4$ ), she employs ecological thinking both literally and metaphorically (51). Our distance from Code's Ecological Thinking emerges when we point out that it is the literal and not the metaphorical view that suffices to unsettle the idea that human beings could be understood in isolation, as some form of physiological and epistemic islands. An updated and more complete ecological view of human organisms pushes away from a mere metaphorical reading of ecology and towards a robust literal view.

${ }^{7}$ Epigenetics might be another example of a similarly overlooked influence on individuality and autonomy- see Paul Hurd (2010).
} 
bacterial diversity in comparison to their lean siblings. However, simply isolating the composition of their respective microbial community would not have been sufficient to establish any clear causal role for the symbionts inhabiting their gut. In response, a team led by Jeffrey Gordon took this study (Ridaura et al 2013) to a new level, deciding to test causation in animal models. They have taken samples of gut microbes from four sets of human twins in which one member was lean and the other obese. Once they introduced the microbes of each respective twin into groups of mice (previously raised in germ-free environments), they have observed weight and metabolic changes, while controlling for their diet. The mice population that had microbial implants from the slim twins remained slim, whereas the mice populations that had microbial implants from the obese twins, quickly gained weight, and have shown direct changes in their metabolisms. Moreover, once lean and obese mice have shared the same cage, a series of microbial transfers from the lean to the obese mice were observed with direct impact on the metabolism of the obese mice. This study has also confirmed not only the importance of a diverse diet low in fat, but also the significant contribution diet plays in highlighting the role of changes in the microbial constitution of individuals and the ecological interconnectedness between our organisms and their surrounding environment.

Thus, we are through and through a biological network - an ecosystem. And, if we fully consider the contribution of the microbiome to human health, we have to radically alter our descriptive views about medical patients and therapeutics since disturbances to our microbial ecosystem become fundamental features of an ecological medical practice (Relman 2012). Obesity is a key example of the importance of an ecological view of biomedicine, bringing together in an ecological way - individual, social, and microbial factors - in the identification and treatment of patients in biomedicine (see Costello et al 2012). Further, these biological and social relations are correlated in terms of their impacts on individual health. Some microbial biologists have claimed that our microbiota can provide us with a reliable measure for malnourishment in postnatal development, and thus, also, a more robust parameter of judging the efficacy of therapeutic food interventions (Subramanian et al 2014). Thus, the autonomous patient is certainly not an atomistic and socially isolated person, but causally and constitutionally constructed both in terms of social and biological relations.

For these reasons the constitutive view of Autonomy 2.0 should be supplemented with a robust ecological view of organisms that indicates the extent to which individuals are affected (constitutively) by those relations. Conceptually, it might be more accurate to understand the individuated self, in terms of its social and biological constituents, as more of a network (a system of biological and social interactions) than a single indivisible individual organism.

The structure of our argument in this section can be separated in two distinct claims. While those claims are interrelated, their lines of argumentation are analytically distinct. The first claim that we defend in this section consists in the idea that human organisms (and, consequently medical patients) cannot be fully conceived/ understood as individuals or selves but should be described as ecosystems. Given the complexity of human organisms, microbial biology provides us with good reasons to believe that in a case of biological composites like us a unique principle of unity that holds all the parts together as one whole does not obtain (Dupré and O'Malley 2007), and that no amount of decomposition can point to any ontological essence (O'Malley and Dupré 2010). Given this ecosystemic picture of the human individual, the following question seems to follow: does Autonomy 2.0 require only a few amendments in order to incorporate this microbial view of human organisms (as in the case of maximum social determination) and reconceive autonomy or, 
given the rich constitutive aspect of human-microbial networks, does the notion of autonomy turn out to be more fiction than fact and a concept that we must jettison $?^{8}$ Does autonomy face a paradigm shift or does it represent a moral fiction?

It is certainly beyond the scope of this paper to propose a fully-fledged answer to this question. However, it is centrally important to acknowledge the complex relationship between a descriptive scientific account of the human individual - one that we have argued is deeply problematic from both social and biological perspectives - and a normative account of individual human worth. The humanist proponent of autonomy as a normative concept may worry that our argument has repugnant implications; specifically, that to let go of autonomy is to deny the fundamental respect for persons that protects individual people in medical research and practice. Not only do we deny that this conclusion follows from our view, but also that autonomy is somehow the only or even the most effective protection of human moral worth.

We believe, as Daniel Dennett believes about the notion of the self (1992), that if autonomy turns out to be a fiction, it might be an efficacious moral fiction (the same way that some moral psychologists have claimed that we should retain the notion of character in spite of its radical critique emerging from the situationist literature in social psychology, e.g. Alfano 2013). ${ }^{9}$ We have good reason in the biomedical context to advocate for autonomy to continue to play a normative and historically informed role as a liberatory and moral standard by which to evaluate individual human worth in biomedicine; particularly, in that context, in order to avoid future human subjects abuses in medical research and practice.

On the other hand given our arguments above, we also believe that the option of abandoning autonomy in medical ethics should not be taken off the table too easily. It would not be outlandish to claim that numerous moral theories can still accomplish if not all then probably most of the moral goals of respect for autonomy without resting on the deontological strength of a concept like autonomy. It has been well argued that some versions of the ethics of care can appeal to different ethical elements than autonomy (like attentiveness, competence, responsiveness, responsibility) while still not diluting their moral reach (Held 2006; Kittay 1999). The consequentialist, too, has resources by which to uphold the normative value of respect for persons without relying on autonomy (Pettit 1989). So, there are moral resources that do not privilege autonomy and are still committed to upholding the value of human individuals. If a suitable normative replacement for the values that autonomy has traditionally upheld can be identified, we see no reason not to jettison the concept. However, those options certainly require further development in order to assess their moral viability in the medical setting.

\footnotetext{
${ }^{8}$ In addition, recent literature from moral psychology and cognitive science has profoundly impacted the possibility for robustly autonomous decisions, denying a sharp line between psychological and biological perspectives. Whether we think of dual-system or dual-process theories of the mind (Bargh 1999; Smith \& Collins 2009) or of implicit bias views of human agency (Banaji \& Greenwald 2013), those views reject the rationalistic picture of human agency and highlights the very significant role of unconscious biases in our behavior (Haidt 2012).

${ }^{9}$ There are interesting questions that remain to be asked about the relationship between our view and a view of collective agency/autonomy of corporations from a legal perspective. We believe that a collective agency view, like that of Philip Pettit (2011), relies heavily on a coherent set of shared preferences/values, which our microbial ecosystemic view might call into question. Thanks to Arthur Caplan for his bringing this future angle of inquiry to our attention.
} 


\section{Concluding Remarks}

We have argued that the structure of the critique of autonomy and of the individual patient in medical bioethics that undergirds it is meted out by relational autonomy is likewise applicable to relational autonomy itself. If Autonomy 2.0 threatens the conceptual coherence of autonomy via causally and constitutively efficacious socially interactions, then Autonomy 3.0 threatens its coherence even further by compounding social and biological interactions. A clearer conception of both individuality and autonomy of the patient in biomedicine is required to address the challenges raised by microbial biology. When understood in terms of the emerging story of microbial communities, organisms are constituted as ecosystems or communities - not as individuals - by a rich network of ecological connections. The attempted recovery of autonomy by Autonomy 2.0, grounded as it remains on the individualistic, causally constrained nature of the individual, is further threatened. This view of the individuated self pushes forward the existing story about the role of social interactions making up the individual inward to focus on the additional biological ways that individual is constituted.

Yet such additional support for the constitutive story acts as a prolegomenon to any future use of autonomy in bioethics. Autonomy, threatened now both by social relations and microbial relations, loses its firm conceptual boundaries and becomes increasingly porous (cf. Tuana 2007). The central question becomes: how porous can the concept autonomy become before all its content has drained out and replaced with a homogenized admixture of related concepts? That is, how porous can the concept become before the content that has made it up is undifferentiable from the content of other surrounding concepts? If we take seriously the strengthened constitutive account of the individual - again, more centrally constituted by relations than merely causally affected by them - does the very idea of the individual (which, again, should not be confused with the idea of the individuated self or ecosystem) lose its practical and coherent meaning? The decision concerning future reliance on concepts like autonomy and individuality have significant implications for health and healthcare. Indeed, there seems to be sufficient reason to understand and treat patients as more than isolated individuals and even more than affected by their social communities but, instead, as communities themselves. Patient-centered care becomes a much more robust and complex notion on such a view. ${ }^{10}$ And if such a view of the individual grounds bioethical understanding of autonomy, then the stretch to re-specify the concept in this context is so radical that it may require a different concept altogether, significantly closer to what ecologists call "ecosystem management" (Costello et al 2012). Additionally, if bioethics intends to hold fast to the normative importance of autonomy as upholding individual human moral worth, it may well become a mere heuristic to be used pragmatically to protect the perceived individual from egregious harms rather than a metaphysically grounded claim about the nature of the individual patient.

If feminist responses complicate the normative place of the autonomous self-directing subject as the units of care and unit of value in biomedicine from Autonomy 1.0, the parallel biological critique of Autonomy 2.0 gives further reasons to consider discarding autonomy as the descriptive frame through which to understand the nature of patients in biomedicine as the foundation upon which

\footnotetext{
${ }^{10}$ We think that this novel view of patient-centered care also blurs some conceptual and disciplinary boundaries between patient care and public health.
} 
their moral worth is evaluated. Amending the concept further may leave it incoherent, unable to sufficiently support the biomedical intuitions that have grounded patient care for so long.

\section{ACKNOWLEDGEMENTS:}

Many thanks to Jason Scott Robert, Ana Iltis, Arthur Caplan, and Brendan Bohannan for their comments on an early draft of this paper. Our thanks go also to the anonymous reviewers for their insightful comments.

\section{REFERENCES:}

Akabayashi, A. \& Hayashi, Y. 2014. "Informed Consent Revisited.” In The Future of Bioethics: International Dialogues. Ed. A. Akabayashi. Oxford: Oxford University Press: 735-749.

Alfano, M. 2013. Character as a Moral Fiction, (Cambridge: Cambridge University Press).

Bäckhed, F., RE Ley, JL Sonnenburg, DA Peterson, JI Gordon. 2005. "Host-Bacterial Mutualism in the Human Intestine." Science 307, no. 1915: 1915-1920.

Baier, A. 1981. "Cartesian Persons.” Philosophia 10, no 3-4: 169-188.

Banaji, M. \& Greenwald, A. 2013. Blind Spot - Hidden Biases of Good People, NY: Delacorte Press.

Bapteste, E. \& Dupré, J. 2013. “Towards a processual microbial ontology.” Biology and Philosophy, 28(2): 379-404.

Bargh, J. 1999. "Cognitive Monster: The Case Against the Controllability of Automatic Stereotype Effects," in Dual-Process Theories in Social Psychology: 361-382. Eds. Chaiken \& Trope, New York: Guilford Press.

Barclay, L. 2000. “Autonomy and the Social Self.” In Relational Autonomy: 52-71. Ed. C. MacKenzie \& N. Stoljar. New York: Oxford University Press.

Beauchamp, T. L. \& Childress, J. F. 2013. Principles of Biomedical Ethics: Seventh Edition. New York: Oxford University Press.

Bohannan, B. 2013. "The Human Body as an Ecosystem," TEDx Talk, available at: https: / / www. youtube.com/watch?v=Dfy2qYfUWE0.

Bravo, JA, Forsythe P, Chew MV, Escaravage E, Savignac HM, Dinan TG, Bienenstock J, Cryan JF. 2011. "Ingestion of Lactobacillus Strain Regulates Emotional Behavior and Central GABA

Receptor Expression in Mouse Via the Vague Nerve,” PNAS, 108(38): 16050-16055.

Callahan, D. 2013. "Obesity Chasing an Elusive Epidemic," The Hasting Center Report 43, no. 1: 3440 . 
CDC.gov. 2014. “Tuskegee Study: Timeline.” http://www.cdc.gov/tuskegee/timeline.htm. Accessed 11.14.14.

Childress, J. F. 1990. “The Place of Autonomy in Bioethics.” The Hastings Center Report Jan/Feb. 1217.

Christman, J. 2004. "Relational Autonomy, Liberal Individualism, and the Social Constitution of Selves.” Philosophical Studies 117: 143-164.

Christman, J. 2009. The Politics of Persons: Individual Autonomy and Socio-Historical Selves. Cambridge: Cambridge University Press.

Christman, J. 2014. "Relational Autonomy and the Social Dynamics of Paternalism." Ethical Theory and Moral Practice 17: 369-382.

Clarke, E. 2011. "The Problem of Biological Individuality”. Biological Theory 5, no. 4: 312-325.

Code, L. 2006. Ecological Thinking: The Politics of Epistemic Location. New York: Oxford University Press.

Costello, EK, Stagaman K, Dethlefsen L, Bohannan BJ, Relman DA. 2012. "The Application of Ecological Theory toward an Understanding of the Human Microbiome," Science 336:1255-1262.

Cryan, J.F. \& O’Mahony, S.M. 2011. “The Microbiome-Gut-Brain-Axis: from Bowel to Behavior”. Neurogastroenterology and Motility, 23:187-192.

Cryan, J.F. \& Dinan, T. "Mind-altering microorganisms: the impact of the gut microbiota on the brain and behavior", Nature Neuroscience, 13:701-712.

Dennett, D. 1992. "The Self as a Center of Narrative Gravity.” In Self and Consciousness: Multiple Perspectives: 275-288. Eds. F. Kessel, P. Cole \& D. Johnson, Hillsdale, NJ: Erlbaum.

Donchin, A. 2000. "Autonomy and Interdependence: Quandries in Genetic Decision-Making." In Relational Autonomy: 236-258. Ed. Catriona MacKenzie and Natalie Stoljar. New York: Oxford University Press.

Drenthen M, Keulartz FWJ, \& Proctor J (eds). 2009. New Visions of Nature - Complexity and Authenticity. New York: Springer.

Dupré, J. 2008. The Constituents of Life. Amsterdam: Van Gorcum.

Dupré, J. 2012. Processes of Life: Essays in the Philosophy of Biology. Oxford: Oxford University Press.

Dupré, J. \& O’Malley, M. 2007. “Metagenomics and Biological Ontology”, Studies in the History and Philosophy of Biology \& Biomedical Science. 38: 834-846. 
Dupré, J. \& O’Malley, M. 2010. “The MetagenomicWorld-View: A Comment on Eric T.

Juengst's 'Metagenomic Metaphors'.” In New Visions of Nature - Complexity and Authenticity: 147-153.

Eds. M. Drenthen, J. Keulartz, \& J. Proctor. New York: Springer.

Foster, J.A. and Neufeld, K.A. 2013. Gut-Brain axis: How the Microbiome Influences Anxiety and Depression. Trends in Neurosciences, 36(5): 305-312

Gilbert, S., Sapp, J, Tauber, A. 2013. “A Symbiotic View of Life: We Have Never Been Individuals," The Quarterly Review of Biology, 87(4):325-341

Gordon J, Ley RE, Wilson R, Mardis E, Xu J, Fraser CM, Relman DA. 2005. Extending Our View of Self: The Human Gut Microbiome Initiative. Available at http://www.genome.gov/Pages/Research/Sequencing/SeqProposals/HGMISeq.pdf.

Gordon JI, \& Klaenhammer TR. 2011. “A Rendezvous with Our Microbes”. PNAS 108(1): 45134515.

Haidt, J. 2012. The Righteous Mind Why Good People are Divided by Politics and Religion. New York: Pantheon Books.

Hari Dass, S.A. \& Vyas, A. 2014. "Toxoplasma Gondii Infection Reduces Predator Aversion in Rats through Epigenetic Modulation in the Host Medial Amygdala”, Molecular Ecology, published online: DOI: $10.1111 /$ mec. 12888 .

Hehemann J-H, Correc G, Barbeyron T, Helbert W, Czjzek M, \& Michel G. 2010. "Transfer of Carbohydrate-Active Enzymes from Marine Bacteria to Japanese Gut Microbiota.” Nature, 464(April 8): 908-12.

Held, V. 2006. The Ethics of Care: Personal, Political, Global. New York: Oxford University Press.

Hertzman, C. 2006. "The Biological Embedding of Early Experience and Its Effects on Health in 
Adulthood.” Annals of the New York Academy of Sciences. 85-95.

Hertzman C. \& Boyce, T. 2010. "How Experience Gets Under the Skin to Create Gradients in Developmental Health.” Annual Review of Public Health 31: 329-47.

Hurd, P. 2010. “The Era of Epigenetics.” Briefings in Functional Genomics 9(5-6): 425-428.

Joffe S, Manocchia M, Weeks JC, Cleary PD. 2003. "What Do Patients Value in Their Hospital Care? An Empirical Perspective on Autonomy Centred Bioethics.” Journal of Medical Ethics 29: 103108.

Juengst, E. 2010. “Metagenomic Metaphors: New Images of the Human from 'Translational' Genomic Research.” In New Visions of Nature - Complexity and Authenticity: 129-145. Eds. M.

Drenthen, J. Keulartz, and J. Proctor. New York: Springer.

Keim, B. 2010. “Gut Bacteria Give Super Seaweed-Digestion Power to Japanese.” Wired. Available at http://www.wired.com/2010/04/sushi-guts/.

Kittay, EF. 1999. Love's Labor: Essays on Women, Equality and Dependency. New York: Routledge.

Kurokawa K, Itoh T, Kuwahara T, Oshima K, Toh H, Toyoda A, Takami H, Morita H, Sharma VK, Srivastava TP, Taylor TD, Noguchi H, Mori H, Ogura Y, Ehrlich DS, Itoh K, Takagi T, Sakaki Y, Hayashi T, \& Hattori M. 2007. “Comparative Metagenomics Revealed Commonly Enriched Gene Sets in Human Gut Microbiomes.” DNA Research, 14: 169-81.

Lema, SC. 2014. “The Ethical Implications of Organism-Environment Interdependency.” Environmental Ethics 36: 151-169.

Levine, RJ. 1975. “The Nature and Definition of Informed Consent in Various Research Settings.” The Belmont Report Appendix I. 3-1 to 3-91. 
Lewontin, RC. 2000. The Triple Helix: Gene, Organism and Environment. Harvard University Press: Cambridge, Mass.

Ley RE, Turnbaugh PJ, Klain S, \& Gordon JI. 2006. "Human Gut Microbes Linked to Obesity.” Nature 444: 1022-1023.

Marshall P, Thomasma DC, Bergsma J. 1994. "Intercultural Reasoning: The Challenge for International Bioethics.” Cambridge Quarterly of Healthcare Ethics 3(3) (1994): 321-328.

MacKenzie C, \& Stoljar N. (eds). 2000. Relational Autonomy. New York: Oxford University Press.

Mayer, E., Knight, R., Mazmanian, S., Cryan, J., Tillisch, K. "Gut Microbes and the Brain: Paradigm Shift in Neuroscience", The Journal of Neuroscience, 34(46):15490-15496.

McLeod, C. \& Sherwin S. 2000. "Relational Autonomy, Self-Trust, and Health Care for Patients Who are Oppressed.” In Relational Autonomy: 259-279. ed. Catriona MacKenzie and Natalie Stoljar. New York: Oxford University Press.

National Commission for the Protection of Human Subjects of Biomedical and Behavioral Research. 1978. “The Belmont Report: Ethical Principles and Guidelines for the Protection of Human Subjects of Research.” DHEW Publication No. (OS) 78-0012.

National Commission for the Protection of Human Subjects of Biomedical and Behavioral Research. 1978b. "The Belmont Report: Ethical Principles and Guidelines for the Protection of Human Subjects of Research: Appendix Volume I.” DHEW Publication No. (OS) 78-0013.

Nature. 2008. "Editorial: Who are We?" Nature, 453(29 May):7195: 563.

Nedelsky, J. 2011. Law's Relations: A Relational Theory of Self, Autonomy, and Law. New York: Oxford University Press. 
Nedelsky, J. 1989. “Reconceiving Autonomy: Sources, Thoughts and Possibilities.” Yale Journal of Law and Feminism 1(7): 7-36.

Nielsen, MEJ \& Andersen MM. 2014. "Should We Hold the Obese Responsible?” Cambridge Quarterly of Healthcare Ethics, 23:443-451.

O’Malley, M. 2014. Philosophy of Microbiology. Cambridge: Cambridge University Press.

O’Malley, M. \& Dupré, J. 2007. “Size Does Not Matter: Towards a More Inclusive Philosophy of Biology.” Biology and Philosophy, 22:155-191.

O’Malley, M. \& Dupré, J. 2010. "Philosophical Themes in Metagenomics," in Metagenomics: Theory, Methods and Applications: 183-209. Ed. D. Marco. Norfolk: Caister Academic Press.

Oyama, S. 2000. The Ontogeny of Information: Developmental Systems and Evolution, Second Edition.

Durham, N.C.: Duke University Press.

Oyama S, Griffiths PE, \& Gray RD 2001. Cycles of Contingency: Developmental Systems and Evolution. Cambridge: MIT Press.

Pettit, P. 2011. Group Agency: The Possibility, Design, and Status of Corporate Agents. Oxford: Oxford University Press.

Pettit, P. 1989. “Consequentialism and Respect for Persons,” Ethics 100(1): 124-6.

Ravel J, Blaser MJ, Braun J, Brown E, Bushman FD, Chang EB, Davies J, Dewy KG, Dinan T, Dominguez-Bello M, Erdman SE, Finlay BB, Garrett WS, Huffnagle GB, Huttenhower C, Jansson J, Jeffrey IB, Jobin C, Khoruts A, Kong HH, Lampe JW, Ley RE, Littman DR, Mazmanian SK, Mills DA, Neish AS, Petrof E, Relman DA, Rhodes R, Turnbuagh PJ, Young VB, Knight R, \& White, O. 2014. "Human Microbiome Science: Visions for the Future, Bethesda, MD, July 24 to 26, 2013”, Microbiome 2(16), doi:10.1186/2049-2618-2-16. 
Relman, D. 2012. “The Human Microbiome: Ecosystem Resilience and Health”, Nutrition Reviews 70(Suppl.1): S2-S9

Rhodes, R., Gligorov, N., \&Schwab, A. P. 2013. The Human Microbiome: Ethical, Legal and Social Concerns. Oxford: Oxford University Press.

Ridaura VK, Faith JJ, Rey FE, Cheng J, Duncan AE, Kau AL, Griffin NW, Lombard V, Henrissat B, Bain JR, Muehlbauer MJ, Ilkayeva O, Semenkovich CF, Funai K. Hayashi DK, Lyle BJ, Martini MC, Ursell LK, Clemente JC, Van Treuren W, Walters WA, Knight R, Newgard CB, Heath AC, \& Gordon JI. 2013. “Gut Microbiota from Twins Discordant for Obesity Modulate Metabolism in Mice," Science 341(6150), DOI: 10.1126/science. 1241214

Robert, JS.2006. Embryology, Epigenesis, and Evolution: Taking Developmental Seriously. Cambridge: Cambridge University Press.

Sherwin, S. 2000. "A Relational Approach to Autonomy in Health Care”, Readings in Health Care Ethics: 69-87. Eds, E. Boetzkes \& W. Waluchow. Ontario: Broadview Press.

Sleator, R. 2010. “The Human Superorganism of Microbes and Men.” Medical Hypotheses 74(2): 214-5.

Smith ER. \& Collins EC. 2009. Dual-Process Models: A Social Psychological

Perspective.' In Two Minds: Dual Processes and Beyond: 197-216. Eds. J. St. B. T. Evans \& K, Frankish. Oxford: Oxford University Press.

Subramanian S, Huq S, Yatsunenko T, Haque R, Mahfuz M, Alam MA, Benezra A, DeStefano J, Meier MF, Muegge BD, Barratt MJ, VanArendonk LG, Zhang Q, Privince MA, Petri Jr. WA, Ahmed T, \& Gordon JI. 2014. "Persistent Gut Microbiota Immaturity in Malnourished Bangladeshi Children.” Nature 510: 417-421, doi: 10.1038/nature13421 
Stoljar, N. 2013. "Feminist Perspectives on Autonomy”, Stanford Encyclopedia of Philosophy, ed. E. Zalta, available at: http://plato.stanford.edu/archives/spr2014/entries/feminism-autonomy.

Tuana, N. 2007. "Viscous Porosity: Witnessing Katrina.” Material Feminisms: 188-213. Ed. S.

Hekman \& S. Alaimo. Durham: Duke University Press.

Turnbaugh PJ, Ley RE, Mahowald MA, Magrini V, Mardis ER, \& Gordon JI. 2006. “An ObesityAssociated Gut Microbiome with Increased Capacity for Energy Harvest.” Nature 444:1027-1031.

Veatch, R. 1976. "Three Theories of Informed Consent: Philosophical Foundations and Policy Implications." The Belmont Report Appendix II. 26-1 to 26-66.

Williams, S. 2013. "The Other Microbiome”. PNAS. Doi/10.1073/pnas. 1300923110

Wilson, R. 2005. Genes and the Agents of Life: The Individual in the Fragile Sciences: Biology. New York: Cambridge University Press.

Wilson, R. \& Barker, M. 2013. The Biological Notion of Individual. Stanford Encyclopedia of Philosophy. URL: http://plato.stanford.edu/entries/biology-individual/

Xu, J \& Gordon, J. 2003. "Honor Thy Symbionts.” PNAS 100(18): 10452-59. 